\title{
Peran Dewan Keamanan dalam Mewujudkan Perdamaian dan Keamanan Internasional (Studi Kasus Perang di Bekas Wilayah Yugoslavia)
}

\section{Sefriani}

\begin{abstract}
This article attempts to describe several roles of the Security Council of the United Nations in keeping intemational peace and security as its main duty. In addition, what obstacles for the board in implementing its duty and how its development recently is, will be discussed in the article. Moreover, this writing tries to review the cases of law enforcement conducted by the Security Council in the Bosnia Herzegovina war as the actual topic to look over. .
\end{abstract}

\section{Pendahụlụan}

PBB merupakan organisasi internasional yang paling lama dapat bertahan dibandingkan dengan organisasi internasional lainnya, seperti Liga Bangsa-Bangsa yang hanya dapat bertahan selama 26 tahun. Selama 56 tahun, PBB mengalami perkembangan, baik dalam jumlah kegiatan;, jumiah anggota, sampai dengan jumlah badan-badan di bawah naungannya.

Di balik perkembangan tersebut, PBB khususnya Dewan 'Keamanan (DK) dinilai banyak mengalami kegagalan. Berbagai

konflik baik dalam skala regional maupunn, internasional banyak yang tidak dapat diselesaikan oleh DK. Masalah Terusan Suez, Palestina, Korea, Kongo, Kamboja, Chili, Haiti, Somalia banyak digunakan sebagai contoh kasus kegagalan DK mewujudkan perdamaian dan kemanan internasional.' Dari kegagalankegaglan tersebut, tidaklah heran apabila banyak pihak yang menghendaki restrukturisasi, revitälișasi, demokratisasi, sampai ke pembubaran PBB, yang sebenarnya berangkat. dari kekecewaan terhadap DK. ${ }^{2}$

Untuk empat masalah pertama dapat dibaca lebih rinci dalam Weiss. et. al. 1997. The United Nations and Changing World Polotics. Second Edition. Westview Press. HIm. 46-52.

'Banyak sekali tulisan-tulisan yang memuat hal ini dalam surat kabar maupun jurnal baik publikasi nasional maupun internasional. 
Dasar Hukum dan Mekanisme DK Mewujudkan Perdamaian dan Keamanan Internasionàl.

Berdasárkan Pasal 24 : Piagam PBB, tanggung jawab utama DK memelihara perdamaian dan keamanan internasional. Untukitu, para anggota PBB menyetujui bahwa dalam melaksanakan kewajiban atau tanggung jawab utamanya itu, DK bertindak. atas nama mereka. Selanjutnya, berdasarkan BAB VII Piagam. PBB, Dewan keamanan dapat' menjatuhkan sanksi kepada negara anggota PBB dalam 3 hal. Pertamà, jikà negara itu mengadakan tindakan-tindakan yang mengancam perdamaian. Kedua, àpabila mëlanggar perdamaian, dan yạng ketiga adaläh apabila negara itu melancarkan suatu agresi terhadap negara lain ${ }^{3}$.

Dari ketentuan-ketentuan di atas, nampak bahwa pelanggaran tertiadap perdamaian dan keamanan internasional oleh negara anggota PBB dapat dikenakan sànksi oleh DK. Piagam tidák memberikan penjélasañ lébih lanjüt mengenai apa yang dimaksud dengan perdamaian dan keamanan internasional, atau tindakan yang bagaimana yang tergolong pelanggaran terhadap perdamaian dan keamanan intemasional. Apa yang ditemukan dalam Piagam 'PBB' adalah sekedar pembedaañ "tindakan-tindäkan" yàng mengancam perdamaian dàn keamanan internasiónal dalam 'duá pengertian.
Pengertian pertama; yaitu dalam kerangka Pasal 34 Piagám PBB, di mana terjadi. pertikaian antar negara yang berlanjut, yang mungkin dapat mengancam perdamaian dan tidak akan dîkuti dengań sanksi. Péngertian kedua adalah di dalam kerangka BAB VII Piagam PBB, yaitu menyangkut tindakan yang dilakukan oleh suatu negara yang melanggar prinsip-prinsip PBB, yang secara langsung dapat mèngançām perdámáian dần keamanan internasional dan dapat dikenakan: sanksi menurut Pasal 51 Piagam PBB. ${ }^{4}$

Dengan demikian, tidak ada ketentuan yang baku mengenai tindakan bagaimana: kategori pelanggaran terhadap perdamaian; dan keamanan internasional. Para anggota DK khususnya anggota tetaplah yang akan? berperan besar dalam menetapkan apakah: suatu tindakan yang dilakukan oleh suatu negara anggota merupakan ancaman terhadap perdamaian dan keamanan internasional'atau tidak. Hal inilah yang merupakan salah satu kelemahan - OK. Akibat 'ketidakjelasan pengaturan mengenai hal ini, maka DK sering memberikan standar ganda dalammemberikan pertimbangan atau memutuskan, apakah telah terjadi ancaman terhadap perdamaian dan keamanan internasional atau tidak.

Apabila, berdasarkan pertimbangan DK telah terjadi ancaman atau pelanggaran terhadap . perdamaian dan keamanan internasional, maka meskipun tidak dinyatakan

'Pasal 39 Piagam PBB menetapkan bahwa DK akan menentukan adanya suatu ancaman terhadap perdamaian, pengacauan terhadap perdamaian atau tindakan agresi dan akan memberikan anjuran-anjuran atau memutuskan tindakan-tindakan apa yang akan diambil sesuai dengan Pasal 41 : dan. 42 untuk memelihara dan mmeulihkan perdamaian dan keamanan internasional.

‘Sumaryo Suryokusumo. 1993. Studi kasus Hukum Organisasilntemasional. Bandung: Alumni.HIm. 29. 
secara eksplisit oleh Piagam PBB mengenai tindakan-tindaan apa saja yang harus diambil oleh PBB, DK dapat mengambil tindakan dari ketentuan-ketentuan yang ada serta kebiasaan yang berlaku dalam hukum internasional. Tahapan tindakan-tindakan itu, antara lain:
a. Preventive Diplomacy
b. Peacemaking
c. Peacekeeping
d. Peacebuilding

Rangkaian pengertian dari tindakantindakan tersebut, adalah seperti yang dikemukakan secara singkat oleh BoutosBoutros Ghali: ${ }^{5}$

The terms preventive diplomacy, peacemaking and peacekeeping are integrally related and as used in this report are defined is follow:

1. Preventive Diplomacy is action to prevent disputes from anising between parties, to prevent existing disputes from escalating into conflicts and to limit the spread of the letter when they occur

2. Peacemaking is action to bring hostile parties to agreement, essentially through such peacefulmeans as those foreseen in Chapter VI of the Charter of the United Nations

3. Peacekeeping is the deployment of a
United Nations presence in the field; hitherto with the onsent of all the parties conserned, normally involvomg United Nations military or policy personnal and frequently civilians as well. Peacekeeping is technique that expands the posibilities for both the prevention of conflict and the making of peace. ${ }^{6}$

Peacebuilding adalah aksi yang dilakukan setelah berakhimya konflik untuk menciptakan kondisi yang lebih menjamin makin terbinanya suasana damai antara pihak-pihak yang telah mengakhiri sengketa ${ }^{7}$ Tahapan-tahapan tersebut di atas sedianya dilaksanakan oleh DK dalam upayanya menyelesaikan suatu konflik guna menciptakan perdamaian dan keamanan internasional.

Masih berkaitan dengan mekanisme mewujudkan perdamaian dan keamanan internasioanal. Di samping Pasal 39 Piagam. PBB yang memberikan kewenangan pada $\mathrm{DK}$ untuk menentukan langkah-langkah apa yang seharusnya diambil guna mencegah setiap upaya yang dapat mengancam perdamaian dan keamanan internasional, dapat pula dikemukakan di sini bahwa DK dapat membentuk organ-organ subsider yang dianggap perlu guna pelaksanaan fungsifungsinya. ${ }^{8}$

5Boutros-Boutros Ghali. 1992. An Agenda for Peace. New York: United Nations. HIm. 11.

${ }^{B} B a n d i n g k a n$ pengertian ini dengan pengertian yang diberikan oleh PBB bahwa Peacekeeping adalah ...a technique of using troops under UN command to keep disputing countries or communities from fighting while peace making effort are pursued. It help create an atmosphere in which fruitful negotiations for peace can be held...United Nations. 1990. Teaching About United Nations Peacekeeping. UN. New York: Department of Public information. HIm. 8.

${ }^{7}$ Adji Samekto. "Mengkaji Peran Operasi Pemeliharaan Perdamaian PBB Sebagai Bagian Upaya Menciptakan Perdamaian Dunia." Dalam Majalah Hukum dan Pembangunan. Pebruari 1991. HIm.28.

${ }^{8}$ Kewenangan ini dapat ditemukan dalam Pasal 29 Piagam PBB. 


\section{Dewan Keamanan pada Era dan Pasca Perang Dingin}

Selama 45 tahun berdiri (1945-1990) kegiatan-kegiatan PBB ditandai oleh pasang surutnya perang dingin, di mana pertentangan blok Barat dan blok Timur sangat mempengaruhi perkembangan dan fungsi organisasi internasional tersebut. ${ }^{9}$ Pada masa itu telah terjadi lebih dari 150 konflik bersenjata di berbagai kawasan dunia yang telah menelan korban tidak kurang dari 20 juta jiwa. ${ }^{10}$ Jumlah ini telah membengkak mencapai lebih dari 24 juta jiwa pada tahun 1995." .

Konflik-konflik bersenjata di atas, tidak semuanya dapat diatasi oleh PBB, khususnya DK yang mempunyai tanggung jawab penuh terhadap pemeliharaan perdamaian dan keamanan internasional. Hal itu menurut Sumaryo Suryokusumo disebabkan oleh karena pertentangan antar blok yang terefleksikan dalam sidang-sidang DK, sehingga-sidang-sidang untuk mengambil keputusan senantiasa diwarnai oleh veto yang dijatuhkan oleh para:anggota tetap badan tersebut. Pada Kurun waktu-1945-1990, sampai pada usianya perang dingin, tercatat ada 279 veto yang dijatuhkan. ${ }^{12}$. Hal ini tentu saja sangat menghambat: kinerja badan tersebut. Terlebih mengingat berdasarkan Pasal 27 ayat (3) Piagam PBB, suara bulat anggota tetap Dewan Keamanañ adalah menjadi syarat mutlak untuk mengambil keputusan mengenai masalah-masalah non prosedural. ${ }^{13}$ Konflik-konflik yang ada menjadi berlarut-larut tidak dapat terselesaikan, demikian pula law enforcement yang sedianya harus ditegakkan oleh DK terhadap pihakpihak yang mengancam perdamaian dan keamanan internasional.

Selama 45 tahun dapat dikatakan bahwa DK tidak penah melakukan law enforcement. Sanksi ekonomi memang pernah diterapkan terhadap Rhodesia Selatan pada tanggal 16 Desember 1966, tetapi tidak efektif karena dilanggar sendiri oleh beberapa anggota tetap DK. ${ }^{14}$.

'Sumaryo Suryokusumo. Op.Cit. HIm. 40.

${ }^{10}$ Boutros-Boutros Ghali. Loc.Cit. HIm. 2. .

"ICRC-IPU. Respect for International Humanitarian Law, Handbook for Parliamentarians. No.I. 1999. HIm.10.

${ }^{12}$ Sumaryo Suryokusumo. Op.Cit. Hlm. 41.

${ }^{13}$ D.W., Bowett. 1975. The Law of International Institutional. London: Steven \& Sons Ltd. HIm. 28-30. Uni Soviet adalah negara yang paling sering menjatukan veto sehingga wakil tetapnya di DK mendapat julukan "Mr Veto". Pada tahun 1980 saat sidang akan memutuskan sanksi untuk Iran serta resolusi untuk Afghanistan, Uni Soviet menjatuhkan vetonya yang ke-146. Keterangan lebih.lanjut dapat dibaca Bantarto Bandoro. "Blok Suara dan Politik Kekuatan di PBB." Dalam Majalah Analisa. 1983. HIm. 9.

${ }^{14}$ Rhodesia Selatan merupakan wilayah yang tidak berpemerintahan sendiri dan diletakkan di bawah pengawasan administrasi Inggris. Selanjutnya secara sepihak Rhodesia Selatan telah memproklamirkan kemerdekaan. Oleh DK tindakan ini dianggap dapat mengancam perdamaian dan keamanan internasional sehingga.DK menjatuhkan saksi ekonomi serta.menyerukan pada dunia untuk tidak memberikan pengakuan atas eksistensi Rhodesia Selatan sebagai negara yang merdeka dan berdaulat, Sumaryo Suryokusumo, op.cit, hlm. 21. 
Setelah berakhirnya pasca perang dingin ternyata DK mengalami dimensi baru. Veto jarang sekali dijatuhkan, sebaliknya sanksisanksi baik sanksi ekonomi maupun militer bergulir satu persatu khususnya terhadap negara-negara sedang berkembang. Sanksi pertama yang masih berlanjut hingga kini dijatuhkan terhadap Irak yang dianggap telah melanggar hukum internasional dengan menginvasi Kuwait pada tahun 1990. Sanksi juga dijatuhkan terhadap Lybia yang tidak mengindahkan permintaan DK untuk mengekstradisi pelaku kejahatan kasus PAN AM 103 dan USA 772 ke Amerika Serikat, Inggris atau Perancis untuk segera diadili. Selanjutnya sanksi juga dijatuhkan pada Yugoslavia pada tahun 1992 karena tidak mengindahkan berbagai resolusi DK berkaitan dengan semakin memburuknya situasi di Bosnia Herzegovina dan tempat-tempat lain di Yugosiavia yang mengancam perdamaian dan keamanan internasional.

Terlepas dari berbagai kritik yang mengemukakan bahwa DK berlebihan, terlalu campur tangan terhadap masalah domestik suatu negara dengan mengatas namakan perdamaian dan keamanan internasional, ${ }^{15}$ berstandar ganda dalam menjatuhkan sanksi, ${ }^{16}$ serta sanksi-sanksi DK hanya diterapkan atau berlaku untuk negara ketiga, nampak bahwa. pasca perang dingin, DK mulai dapat melaksanakan fungsinya melakukan law en- forcement terhadap masalah-masalah yang dipandang dapat mengancam perdamaian dan keamanan internasional.

\section{Peran Dewan Keamanan Mewujudkan Perdamaian dan Keamanan Internasional dalam Perang Bosnia- Herzegovina.}

Kasus Bosnia Herzegovina berawal dari upaya pemisahan diri republik-republik yang semula tergabung daiam Sosialist Federal Republic of Yugoslavia. Pada tahun 1946 Josep Broz Tito memang dapat membentuk republik komunis tersebut yang terdiri dari republik-republik seperti Slovenia, Croatia, Bosnia Herzegovina, Macedonia, Vojvodina, Serbia, dan Montenegro. Di balik kewibawaannya Tito mampu menghilangkan semua perbedaan etnik dan agama terhadap semua republik tersebut di bawah bendera Yugoslavia. ${ }^{17}$

Kondisi mengalami perubahan sepeninggal Tito, serta runtuhnya rejim komunis Uni Soviet, salah satu negara adi daya yang merupakan pilar komunis saat itu. Republik-republik yang tergabung dalam SFRY mulai berkehendak memisahkan diri dan mendirikan negara sendiri, tidak terkecuali Bosnia Herzegovina yang memiliki perbedaan mencolok dengan republik-republik yang lain, di mana mayoritas penduduk Bosnia adalah muslim.

${ }^{15}$ Dalam kasus Irak misalnya, ambisi Amerika Serikat menjatuhkan Saddam Husein disalurkan melalui resolusi-resolusi DK, demikian halnya dengan kasus Somalia dengan Jendral Aididnya.

${ }^{18}$ Pelanggaran resolusi PBB oleh Irak mengakibatkan dijatuhkannya sanksi berkepanjangan oleh PBB, tetapi pelanggaran Resolusi DK No.242 (1967) dan 338 (1973) agar Israel menarik diri dari wilayah-wilayah Arab yang didudukinya secara tidak sah tidak pernah dikuti sanksi baik ekonomi maupun militer sampaj sekarang.

${ }^{17}$ Ensiklopedia Britanica. Micropaedia. Vol 12. 1995. HIm. 870-871. 
Setelah Slovenia dan Croatia menyatakan memisahkan diri pada tanggal 25 Juni 1991, Macedonia pada tanggal 19 Desember 1991, akhimya Bosnia Herzegovina juga menyatakan pemisahan dirinya dari Federasi Yugoslavia pada Februari 1991. Serbia bersama-sama Montenegro bersama-sama membentuk federasi baru dan menyatakan diri sebagai pengganti Yugoslavia sebagaimana diproklamirkan pada tahun 1946. Kelompok etnik Serbia yang berada di Bosnia dan Croatia membentuk kekuatan sendiri dan dengan dibantu oleh Yugoslavia berusaha merebut kantong-kantong wilayah yang berada di bawah pengawasan Bosnia. ${ }^{18}$

Dalam melakukan perebutan wilayah inilah, Serbia yang dipimpin oleh Rodovan Karadzic (Presiden pemerintahan Serbia di Bosnia) dan Radko Mladic (Komandan pasukan pemerintahan Serbia di Bosnia) menghalalkan segala cara untuk merebut wilayah-wilayah Bosnia. Politik cleansing ethnic yaitu pembersihan etnik Bosnia yang beragama Islam dengan menggunakan cara-cara di luar batas-batas kemanusiaan dilakukan. Pembunuhan penduduk sipil secara sistematis, pemerkosaan, penyiksaaan, perampasan harta benda penduduk merupakan fenomena sehari-hari di Bosnia.

Terhadap kejahatan genocide, kejahatan terhadap kemanusiaan, pelanggaran berat Konvensi Jenewa dan pelanggaran terhadap hukum dan kebiasaan perang yang terjadi di Bosnia, kritik dan kecaman dilemparkan pada PBB, khususnya DK karena dianggap tidak melakukan penegakkan hukum, bahkan seolah menyetujui pembersihan etnik muslim di sana. Anggapan ini sebenarnya tidaklah benar seluruhnya. Sejak tanggal 25 September 1991 sampai dengan 15 Mei 1992 DK telah mengeluarkan 8 resolusi berkaitan dengan makin memburuknya situasi di Bosnia, penyerangan terhadap anggota UNPROFOR (United Nations Protection and Force) termasuk anggota Palang Merah Internasional (ICRC), pelanggaran gencatan senjata, pengusiran warga negara yang bukan Serbia dan pelanggaran-pelanggaran hukum internasional lainnya. Tidak diindahkannya resolusi-resolusi tersebut, mendorong DK untuk mengenakan sanksi ekonomi kepada Yugoslavia pada tanggal 25 Mei 1992. Sanksi ekonomi tersebut antara lain sebagai berikut: ${ }^{19}$

a. Melarang impor bahan-bahan mentah dan produksi barang-barang lainnya dari Yugoslavia serta kegiatan apapun yang ditafsirkan dapat meningkatkan ekspornya serta penjualan dan pemasokan dengan menggunakan kapal laut/udara bagi bahan-bahan tersebut.

b. Menghentikan dana bantuan termasuk sumber-sumber ekonomi dan keuangan ke negara tersebut.

c. Tidak memberikan ijin penerbangan termasuk ijin lintas udara untuk pesawatpesawat udara dari Yugoslavia

d. Mengurangi tingkatan staf diplomatik dan konsuler perwakilan Yugoslavia di luar negeri.

e. Melarang keikutsertaan atlet Yugoslavia dalam pekan-pekan olah raga internasional.

${ }^{18} /$ bid.

${ }^{19}$ Sumaryo Suryokusumo. Op.Cit. HIm. 23-24. 
Sanksi-sanksi ekonomi sebagaimana disebutkan, juga keberadaan pasukan penjaga perdamaian PBB (UNPROFOR), serta berbagai upaya diplomasi yang dilakukan PBB ternyata tidaklah efektif. Tekanan dari dunia islam dan negara-negara ketiga makin mendorong DK untuk lebih serius menangani kasus Bosnia. Setelah mengumpulkan buktibukti yang cukup tentang berbagai bentuk pelanggaran terhadap kemanusiaan yang dilakukan di Bosnia, akhirnya DK melälui resolusinya Nomor 827 tahun 1993 membentuk Tribunal atau pengadilan yang berkedudukan di Den Haag bagi penjahatpejahat perang dalam kasus perang di bekas wilayah Yugoslavia. ${ }^{20}$

Bilamana resolusi Majelis Umum yang banyak dikeluarkan pada era perang dingin akibat kegagalan DK mengambil keputusan terhadap pelanggaran perdamaian dan keamanan internasional hanya. bersifat rekomendatif, maka tidaklah demikian dengan resolusi DK. Resolusi ini lebih memiliki kekuatan hukum. yang mengikat, harus dipatuhi oleh semua pihak yang bertikai. Bila terdapat upaya-upaya yang bertentangan dengan penegakkan hukum kejahatan perang dan kemanusiaan ini, komisi bersenjata yang dibentuk DK PBB yaitu IFOR (International Forces) dapat menggunakan kekuatan bersenjata guna menyeret siapa saja yang patut diduga terlibat dalam kejahatan perang maupun kejahatan terhadap kemanusiaan ini.

Dari apa yang dikemukakan dalam kasus Bosnia di atas, nampak bahwa DK telah dapat menjalankan fungsi dan mekanisme kerjanya sesuai dengan piagam PBB. Setelah berbagai forum diplomasi sampai ke sanksi ekonomi mengalami jalan buntu, maka berdasarkan Pasal 24 jo Pasal 39 Piagam PBB, DK dapat mengambil langkah-langkah guna memelihara perdamaian dan keamanan internasional di wilayah Balkan. Pembentukan UNPROFOR merupakan langkah Peacekeeping yang dilakukan oleh DK PBB. Adapun pembentukan Intemational Criminal Tribunal untuk mengadili penjahat perang di Bosnia, meskipun tidak diatur sama sekali oleh Piagam PBB, tetapi bila dihubungkan dengan tugas pokok DK yang diberikan mandat sedemikian besar untuk memelihara perdamaian dan keamanan internasional, maka upaya pembentukan pengadilan tersebut menjadi sangat relevan.

Sebagaimana telah dikemukakan sebelumnya berdasarkan Pasal 39 Piagam PBB, DK dapat menentukan langkah-langkah apa yang harus diambil guna mencegah setiap upaya yang dapat mengancam perdamaian dan keamanan internasional. Di samping itu, berdasarkan Pasal 29 Piagam, DK dapat membentuk organ-organ subsider yang dianggap perlu guna pelaksanaan fungsifungsinya. Oleh karena itu pembentukan

${ }^{20}$ Apa yang menjadi tugas, fungsi, kewenangan serta mekanisme kerja pengadilan internasional ini diatur * dalam Statute of the Intemational Tribunal for the Presecution of Persons Responsible for Serious Violation of International Humanitarian Law Commiteed in The Territory of The Former Yugoslavia since 1991, May 25 1993, Sihombing. "Tanggung Jawab Komando dalam Hukum Humaniter Intemaisonal." Makalah pada Penataran Hukum Humaniter Internaisonal Tingkat Lanjut. Unsri. 24-25 Juni 2000. HIm. 9. 
pengadilan penjahat perang di Den Haag dalam kasus Bosnia adalah juga dimaksudkan untuk lebih menegaskan pelaksanaan fungsifungsi Dewan Keamanan sebagai penjamin terciptanya perdamaian dan keamanan internasional. Apa yang terjadi di Bosnia merupakan praktek uncivilized yang merendahkan harkat dan martabat manusia yang sangat dijunjung tinggi oleh Piagam PBB.

\section{Simpulan}

Pasca perang dingin DK telah lebih dapat menjalankan- fungsinya memelihara perdamaian dan keamanan internasional dibandingkan di era perang dingin. Dengan berbagai kelemahannya, DK sebenarnya telah memberikan banyak sumbangan untuk memperkuat perdamaian dan meredakan konflik-konflik internasional dan mencegah timbulnya perang dunia baru selama lebih lima dasawarsa. DK telah memainkan peran penting dalam penyelesaian sejumlah sengketa internasional. DK telah juga berupaya melakukan penegakkan hukum terhadap negara atau pihak-pihak yang dianggap melanggar perdamaian dan keamanan internasional. Penegakkan hukum melalui pembentukan peradilan internasional untuk penjahat perang dalam kasus Bosnia adalah salah satunya. Di samping pembentukan peradilan serupa untuk kasus Rwanda. Terlepas dari itu semua restrukturisasi terhadap badan ini memang penting untuk dilakukan untuk lebih mengoptimalkan fungsinya sebagai pemelihara perdamaian dan keamanan internasional.

\section{Daftar Pustaka}

Adji Samekto. "Mengkaji Peran Operasi Pemeliharaan Perdamaian PBB Sebagai Bagian Upaya Menciptakan Perdamaian Dunia." Dalam Majalah Hukum dan Pembangunan. Pebruari 1991.

Bantarto Bandoro. "Blok Suara dan Politik Kekuatan di PBB." Dalam Majajah Analisa. 1983.

Boutros Boutros Ghali. An Agenda for Peace. New York: United Nation. 1992.

D.W., Bowett. The Law of International Institutional. London: Steven \& Sons Ltd. 1975

Ensiklopedia Britanica. Micropaedia. Vol 12. 1995

ICRC-IPU. Respect for International Humanitarian Law, Handbook for Parliamentarians. No.I. 1999.

Sihombing. "Tanggung Jawab Komando Dalam Hukum Humaniter Intemasional." Makalah pada Penataran Hukum Humaniter Internasional Tingkat Lanjut. Unsri. 24-25 Juni 2000.

Sumaryo Suryokusumo. Studi Kasus Hukum Organisasi Internasional. Bandung: Alumni. 1993.

United Nations. Teaching About United Nations Peacekeeping. UN. New York: Department of Public Information. 1990

Weiss. et. al. The United Nations and Changing World Politics. Second Edition: Westview Press.1997. 